表 2 モルモット鼻粘膜における NKA および SP の濃度

\begin{tabular}{|c|c|c|c|c|}
\hline 鼻＼cjkstart粘＼cjkstart膜 & 動物数 & $\begin{array}{c}\text { 湿重量 }(\mathrm{mg}) \text { 当りの } \\
\text { NKA 量 }(\mathrm{pg})\end{array}$ & $\begin{array}{c}\text { 湿重量 }(\mathrm{mg}) \text { 当りの } \\
\text { SP 量 }(\mathrm{pg})\end{array}$ & $\mathrm{SP} / \mathrm{NKA}$ \\
\hline 鼻 中 隔 & 5 & $14.4 \pm 1.2$ & $10.5 \pm 0.2$ & 0.7 \\
\hline 鼻甲介その他 & 5 & $21.0 \pm 1.4$ & $19.5 \pm 1.2$ & 0.9 \\
\hline
\end{tabular}

平均値士標準誤差

用いた。 なお Radio-immunoassay では，上澄液を凍 結乾燥後, ${ }^{125}$ I-SP (New England Nuclear), ${ }^{125}$ INKA (Amershan) を使用して Mroz \& Leeman の方 法に従って RIA 測定した。

結果 Adn は血管系, 特に, 静脈系では血管壁に非 常に密な網目状の分布を示すが, 腺組織では腺体およ び導管のいずれにおいてもきわめてわずかしか認め得 ない.Chnは血管系抢よび腺組織ともに密な分布を示 す。一方, peptidergic nerve fiberでは, VIP 含有線 維は Adn, Chnよりかなり少なく，腺体扔よび導管で はかなり多いが血管壁および上皮下組織では少なくな
る. CGRP 含有線維は血管，腺执よび粘膜下層でかな り多く存在する. SP および NKA 含有線維は血管壁, 腺抢よび上皮下層にわずかに存在し，SP拈よび CGRP 線維は粘膜上皮内にも存在している.上記の結 果を総括すると表 1 の通りである。鼻中隔部扔よび鼻 甲介部の $1 \mathrm{mg}$ 当たりの NKA 掞よび $\mathrm{SP}$ 量を比較検 討すると，いずれも鼻甲介部が多い。さらに, NKA と $\mathrm{SP}$ 量 $(\mathrm{SP} / \mathrm{NKA})$ を比較すると, 鼻中隔部では $\mathrm{NKA}$ が SPよりかなり，鼻甲介部では NKA が SP よりわ ずかに多い。その結果は表 2 の通りである。

\title{
12. DISTRIBUTION OF SP, CGRP, AND VIP IN THE GUINEA PIG NASAL MUCOSA SENSITIZED BY TOLUENE DIISOCYANATE (TDI)
}

B. Kalubi（阪大・ザイール，キンシャサ大） 入船盛弘・荻野 敏・松永 亨（阪大）遠山政弥（同・第二解剖）

Toluene disocyanate (TDI) is known to induce clinical symptoms of respiratory hypersensitivity in the mammals including man. Present immunohistochemical study has demonstrated in the Guinea pig that TDI treatment resulted in increase in number and intensity of Substance P (SP) and Calcitonin Gene Related Peptide (CGRP)-like immunoreactive fibers in the nasal mucosa, while failed to cause changes in the distribution of Vasoactive Intestinal Peptide (VIP) immunoreactive fibers.

Introduction It has been demonstrated that stimulation of the sensory nerve fibers in the nasal mucosa of mammals including human causes inflammation ${ }^{3448) 10}$. It is likely that this effect is due to the release of neuroactive substances from the endings of sensory nerve fibers. In fact release of SP and CGRP in the nasal mucosa was confirmed pharmacologicaly in the animals whose nasal mucosa sensory fibers were stimulated. However, it is still unclear whether or not SP and CGRP are reflexly released or they are produced actively from the nerve endings in this animal. Accordingly, in the present study, we have attempted to elucidate the changes of SP, CGRP and VIP immunoreactive fibers in the nasal mucosa after treatment with TDI which is known to cause respiratory hypersen. sitivity.

Material and Methods Guinea pig weighing about $250-300 \mathrm{~g}$ were used in this study. Animals were divided into 2 groups : one treated by TDI and an other was a control group. The sensitization process was done by local and daily application of $10 \%$ TDI solution to the nasal mucosa for 5 days. After 3 weeks of observation, application of $10 \%$ TDI was repeated for an other 5 days period. One week after the final application, 5\% TDI sol. was applied locally for provocation test once a week for 7 weeks. Animals showing a positive reaction (sneezing, rhinorrhea) to the provocation test were selected and nasal mucosa samples were subjected to immunohistochemistry.

Results In the control animals, many SP and CGRP fibers were seen in the nasal mucosa. In the lamina propria, a number of immunoreactive fibers were associated with blood vessels and seromucous glands. Several fibers often left the lamina propria to enter the epithelium. VIP fibers showed a similar distribution pattern to those of SP and CGRP, but very few fibers entered the epithelium. TDI 
treatment resulted in marked increase in number and intensity of SP and CGRP fibers in the lamina propria and in the epithelium, while no clear changes could be detected in the distribution of VIP fibers in the TDI treated animals.

Discussion It has been reported that activation of sensory fibers by local irritation of nasal mucosa using a chemical irritant, causes release of SP or CGRP from the nerve endings. In well accordance with these findings, present immunocytochemical analysis demonstrated the increase in number and intensity of SP and CGRP fibers in the Guinea pig nasal mucosa treated by TDI. Considering the present findings, production of SP and CGRP in the sensory neurons increases in the TDI treated animals. Our findings suggest that TDI treatment resulted in increase of blood flow and glandular secretion, because 1) most of SP and CGRP fibers were located around blood vessels and glands, 2) both SP and CGRP are known to be strong vasodilators ${ }^{8) 11}$ ) and they have been found to be stimulant of airway mucous secretion ${ }^{1)}$.

On the other hand, TDI treatment failed to cause changes of VIP fibers both around blood vessels and glands and within the epithelium, suggesting that TDI doesn't give an influence on the VIPergic nor in sensory fibers of Guinea pig nasal mucosa.

BIBLIOGRAPHY

1) Barnes PJ : Regulatory peptides in the respiratory system, in Regulatory peptides, Birkhauser Verlag, 1989.

2) Bucher BT, Salvaggio JE et al: Toluene diisocyanate pulmonary disease: Immunophar- macologic and mecholyl challenge studies. J Allergy Clin Imm 59 223-227, 1977.

3) Goodman EC and Iversen LL: Calcitonin Generelated Peptide : Novel neuropeptide. Life SC 38: 2169-2178, 1986.

4) Inagaki $S$ and Kito $S$ : Peptides in the peripheral nervous system. in Progress in Brain Research. $66 ; 269-316$.

5) Kumagai $\mathrm{N}$, Kadota $\mathrm{T}$ et al: Deacalcification with EDTA does not affect immunohistochemical activ ity. (unpublished data)

6) Nilsson G, Rak $S$ and Ahlstedt $S$ : The Influence of Substance $P$ on the proliferation of peripheral blood lymphocytes from normal individuals and birch pollen-allergic patients. Allergy $42: 516-523,1987$.

7) Schultzberg M : The Peripheral Nervous System, in Emson PC (ed) Chemical Neuroanatory, 1983 pp 151.

8) Skofitsch G and Jacobowitz DM : Calcitonin Generelated Peptide coexists with Substance P in Cap saicin Sensitive Neurons and Sensory ganglia of the Rat. Peptides, 6: 747-754, 1985.

9) Terenghi G, Polak JM et al: Calcitonin GeneRelated peptide-Immunoreactive nerves in the tongue, Epiglottis and pharynx of the rat: Occurrence, distribution and Origin. Brain Research: 365, 1-14, 1986.

10) Uddman $R$ Malm $L$ and Sundler $F$ : Substance $P$ containing nerve fibers in the Nasal Mucosa. Arch Otorhin : 238: 9-16, 1983 ,

11) Uddman R, Edvinsson $L$ et al : Calcitonin GeneRelated Peptide (CGRP) : perivascular distribution and vasodilatory effects. Regulatory Peptides 15: 1-23, 1986.

\section{3. 反回神経の変性及び再生過程における形態学的観察}

\section{南 仁成（佐賀医大・慶熙大）}

末梢神経は損傷されると損傷部より末梢側はワーラ 一変性におちいるが中枢側は逆行性変性をおこす。一 方では末梢神経特有の強い再生能力を示すことが報告 されている。しかし，反回神経のように同一神経が拮 抗筋を支配している場合には再生が正確に行われない と機能回復にいろいろの障害が生じるのは臨床的ある いは生理学的によく知られている。.今回われわれは軸 索とシュワン細胞などの細胞成分のみを除去する目的 で凍結損傷をモルモットの反回神経に加えその変性と 再生の過程を最長 6 力月まで観察した。末梢部神経の 光顕, 電顕的変化及び HRP 標識法を用いて延髄の内 喉頭筋を支配する運動神経の再配列を観察した。

3 日後に反回神経の損傷部より末梢側では損傷後軸
索がほほ完全に消失し髄鞘の破壊が見られたが 2 週後 には無髄ないし有髄の細い再生軸索が多数観察された 一方, この再生過程において再生神経線維の形態は変 形が著しく完全な神経配列回復の難しさが推測された 中枢運動神経の再配列は神経損傷後モルモットの後筋 にHRP を注入した結果, 3 力月から標識細胞が見え, 標識細胞は徐々に増え続けて 6 力月には正常対照群の 後筋支配運動神経の数とほぼ同じレベルとなった.し かし再生運動神経細胞体の分布を見ると本来の後筋支 配領域以外の細胞体からの投射がおこっていることが 確認された。 反回神経の運動神経には強い再生能が見 られるが，再生神経は正しく再支配するとは限らず正 常な機能回復にとって障害となることが推定される. 